\title{
Changes in Respiratory Rate, Blood Pressure and Heart Rate Variability in Rabbits during Orthostasis
}

\author{
*J. MOKRÝ, **T. REMEŇOVÁ, **K. JAVORKA \\ * Department of Pharmacology, Jessenius Faculty of Medicine, Comenius University, Martin, Slovakia \\ ** Department of Physiology, Jessenius Faculty of Medicine, Comenius University, Martin, Slovakia
}

Received November 8, 2005

Accepted March 16, 2006

\begin{abstract}
Mokrý J, T. Remeňová, K. Javorka: Changes in Respiratory Rate, Blood Pressure and Heart Rate Variability in Rabbits during Orthostasis. Acta Vet. Brno 2006, 75: 3-12.

The purpose of the study was to evaluate the changes of respiratory rate, systemic blood pressure and heart rate variability parameters (HRV) during orthostasis in anaesthetized rabbits. Furthermore, these changes were influenced by affecting the renin-angiotensin-aldosterone (RAA) system and autonomic nervous system (ANS) to study the mechanisms participating in activity of spectral frequency bands of HRV in rabbits.

Ten adult rabbits (Chinchilla) were anaesthetized by ketamine and flunitrazepam. The systemic blood pressure, tidal volume and respiratory rate were measured. HRV was evaluated by microcomputer system VariaPulse TF3E. The R-R intervals were derived from the electrocardiogram signal from subcutaneous needle electrodes. The evaluation of HRV in very low (VLF; 0.01-0.05 Hz), low (LF; 0.05-0.15 Hz) and high frequency bands (HF; 0.15-2.0 Hz) was made and parameters of frequency and time analysis were calculated. The measurements were made in horizontal (supine) position, in orthostasis (the angle of $60^{\circ}$ ) and again in supine position before and after enalapril $(0.5 \mathrm{mg} / \mathrm{kg}$ b.w.), metipranolol $(0.2 \mathrm{mg} / \mathrm{kg} \mathrm{b.w.})$, and after subsequent bilateral cervical vagotomy.

The orthostasis in anaesthetized rabbits is accompanied by depression of respiratory rate reversed only by vagotomy. Furthermore, decrease of systemic blood pressure, unchanged heart rate and increased characteristics of heart rate variability were found, with predominant increase of spectral power in LF and VLF bands. This elevation can be eliminated only by complete blockade of ANS.

Although the participation of ANS or RAA system in modification of individual HRV frequency bands is not as specific as in humans, we confirmed the participation of RAA system in determination of the VLF band.
\end{abstract}

Heart rate variability, renin-angiotensin-aldosteron, blood pressure, respiratory rate, autonomic nervous system, enalapril, rabbits

Orthostatic test is generally used for evaluation of the reactivity of autonomous nervous system (ANS), endocrine system and cardiovascular system to stress. Changing the position from lying to standing results in the blood accumulation in capacity vessels (lower extremities, pelvic and gluteal area) below the level of the heart. This leads to diminishing of the venous return, cardiac filling and cardiac output as well as decrease in systemic arterial blood pressure.

The compensatory mechanisms are mediated via reflexes and humoral substances to keep adequate organ perfusion during orthostasis. The reflex mechanisms are activated by lower afferent impulses from baroreceptors with almost immediate commence. The humoral mechanisms are, however, much slower and they start to participate on compensation after prolonged orthostasis.

The changes of respiration during orthostasis are still not completely known. The body transition from supine to orthostatic position may lead to slowing down or temporary apnea via Hering-Breuer inflation reflex by a decrease of abdominal organs and traction through

Address for correspondence:

MUDr. Juraj Mokrý, PhD.

Department of Pharmacology

Jessenius Faculty of Medicine

Comenius University

Sklabinská 26, 03753 Martin, Slovak Republic

Phone: +421434132535

Fax: +421 434134807

E-mail: mokry@jfmed.uniba.sk

http://www.vfu.cz/acta-vet/actavet.htm 
the diaphragm, as well as to increased thoracic volume (Mortola 1980; Javorka 1992).

The heart rate variability (HRV) measurement and its evaluation by spectral analysis is a suitable, sensitive and non-invasive tool for studying the influence of ANS and endocrine system on the heart (Kleiger et al. 1992). HRV expresses the beat-to-beat regulation of the heart pacemaker, the fine-tuning of heart rate around an average value especially via activity of ANS. The interactions of parasympathetic and sympathetic nervous system together with other intrinsic mechanisms are considered to be essential for quick and short-term changes in HRV (Javorka 1996).

The aim of our study was to evaluate the ability of anaesthetized rabbits to modify respiratory and cardiovascular functions in orthostasis, i.e. respiratory rate, systemic blood pressure (BP) and HRV parameters. Furthermore, these changes were evaluated after administration of angiotensin-converting enzyme (ACE) inhibitor enalapril to affect the renin-angiotensin-aldosterone system and by blockade of ANS using metipranolol and bilateral cervical vagotomy to widen the knowledge about orthostasis and HRV in rabbits.

\section{Materials and Methods}

We used 10 adult rabbits (Chinchilla) with mean body weight (b.w.) of $2.5 \pm 0.5 \mathrm{~kg}$. The animals were housed and bred in central menagerie with standard food and water ad libitum. During the whole experiment the animals were anaesthetized by ketamine (Narkamon 5\%, Léčiva, Czech Republic) at the dose of $0.7 \mathrm{ml} / \mathrm{kg}$ b.w. and flunitrazepam (Rohypnol 2\%, Léčiva, Czech Republic) at the dose of $0.2 \mathrm{ml} / \mathrm{kg} \mathrm{b.w}$. to vena marginalis auriculae. Furthermore, every 30 minutes the combination of ketamine $(0.2 \mathrm{ml} / \mathrm{kg} \mathrm{b.w}$.) and flunitrazepam $(0.07 \mathrm{ml} / \mathrm{kg} \mathrm{b}$.w. $)$ was administered to maintain the sufficient depth of anesthesia. Anesthetics and other drugs were administered through catheter in the right femoral vein. The systemic BP was monitored continuously using the electromanometer (LDP 102, Tesla Valašské Meziř́čí, Czech Republic) connected to catheter in arteria femoralis and recorded with recorder (6 NEK 6, RFT, Dresden, Germany). Pneumotachograph (ÚMMT, Bratislava, Slovak Republic) connected to endotracheal cannula was used for measurement of tidal volume and respiratory rate and recorded by the recorder.

HRV was evaluated by microcomputer system VariaPulse TF3 (Type E for experimental use, SIMA MEDIA, Olomouc, Czech Republic) recording the telemetrically transmitted R-R intervals through a receiver to computer. The R-R intervals were derived from the electrocardiogram (ECG) signal from subcutaneous needle electrodes. Special software using spectral analysis (Fast Fourier Transformation) enables the evaluation of HRV in very low (VLF; 0.01-0.05 Hz), low (LF; 0.05-0.15 Hz) and high frequency bands (HF; 0.15-2.0 Hz) as well as objective and automatic calculation of 21 parameters (Salinger et al. 1993, 1994). Besides total spectral power (TP), this software offers the characteristics of the individual frequency bands - spectral power VLF, LF and HF, power spectral density (PSD VLF, PSD LF, PSD HF), and peak of the frequency in the band. Furthermore, the program calculates ratios between activities in each frequency band and total power (relative power VLF, LF and HF), as well as power ratios (VLF/LF, VLF/HF, LF/HF) useful for evaluation of relative activity of sympathetic or parasympathetic ANS regulating the heart rate at rest and in orthostasis.

The time analysis provides further parameters: R-R intervals (and instantaneous reciprocal heart rate), standard deviation of the R-R intervals (SDRR) and MSSD (mean squared successive differences). Both of these parameters characterize the magnitude of HRV, whereas the other parameters from frequency analysis using fast Fourier analysis of non-harmonic signals informs about the rhythms. The results of spectral analysis are in the form of graphic export protocol (color 3D PSD map positioned on frequency axis of frequency spectrum) as well as in digital form - in numeric tables. Immediate display of current results on the screen, continual evaluation of $H R$ as well as on-line frequency spectrum showing the present status of examined rabbit during the manipulation are big advantages of this method (Javorka 1996; Tonhajzerová 2000).

For eliciting orthostasis, we used an instrument easily to handle allowing raising the animal to the angle of $60^{\circ}$ in relatively short time. The parameters were measured in horizontal (supine) position ( $\mathrm{S} 1$ ), in orthostasis $(\mathrm{O})$ and again in supine position (S2). The animal had to be in each position until $600 \mathrm{R}-\mathrm{R}$ intervals were recorded.

Enalapril (ENAP, Krka, Slovenia) at the dose of $0.5 \mathrm{mg} / \mathrm{kg}$ b.w. was administered intravenously (i.v.) during 5 minutes to influence the renin-angiotensin-aldosterone (RAA) system and the parameters were recorded 30 minutes after the administration. For the inhibition of sympathetic nervous system activity on the heart, metipranolol (TRIMEPRANOL, Hoechst Biotika, Slovakia) at the dose of $0.2 \mathrm{mg} / \mathrm{kg}$ b.w. i.v. was administered to the same animal and the measurement of parameters 30 minutes later was made. Thereafter, bilateral cervical vagotomy with subsequent measurement of all parameter was done to block the influence of parasympathetic nervous system on the heart.

All the measurements were made after the surgical preparation of the animals before administration of any drug (BEFORE), after Enap administration (ENAP), after Trimepranol administration (TMP), and after subsequent vagotomy (VAG). The measurement was repeated twice in each situation. 
The parameters in tables are expressed as means and standard error of the mean $(\mathrm{x} \pm \mathrm{SEM})$. Because the assumptions for using parametric tests according to the Kolmogorov-Smirnov test of distribution were not fulfilled, the Wilcoxon test for within-group comparisons was used for statistical analysis and $p<0.05$ was considered as statistically significant.

\section{Results}

The orthostatic position significantly decreased the respiratory rate in control conditions (BEFORE), after ENAP as well as after TMP administration in rabbits. Subsequent bilateral cervical vagotomy significantly depressed the respiratory rate already in supine position. Surprisingly, during orthostasis after vagotomy no decrease, but significant increase in respiratory rate was found (Table 1, Fig. 1).

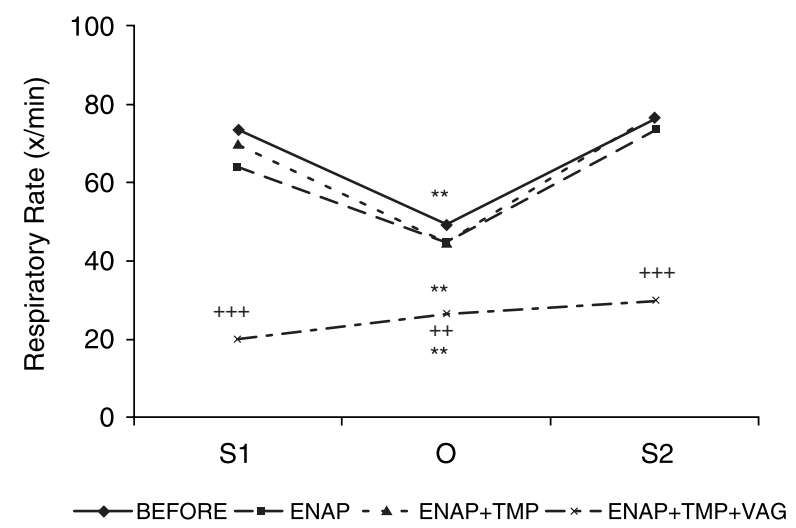

Fig. 1. Changes of respiratory rate (for explanations see the text, for SEM see Tab. 1).

Significant change of parameter during orthostasis (O vs S1): $* p<0.05, * * p<0.01, * * * p<0.001$. Significant change of parameter vs BEFORE: $+p<0.05,++p<0.01,+++p<0.001$.

The orthostatic position $(\mathrm{O})$ caused significant decrease in diastolic BP BEFORE, after ENAP, TMP as well as after vagotomy (VAG); in consecutive supine position (S2) an increase in diastolic BP was observed with no significant difference comparing to S1. Administration of ENAP decreased the diastolic BP in S1, and S2 positions comparing to BEFORE (Table 1, Fig. 2). The systolic BP changes were analogical to diastolic BP (Table 1).

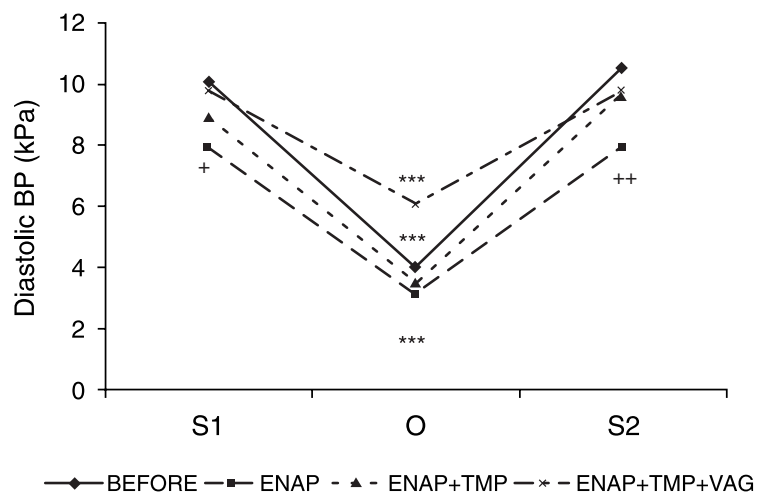

Fig. 2. Changes of diastolic BP (for explanations see the text, for SEM see Tab. 1).

Significant change of parameter during orthostasis (O vs S1): $* p<0.05, * * p<0.01, * * * p<0.001$. Significant change of parameter vs BEFORE: $+p<0.05,++p<0.01,+++p<0.001$. 


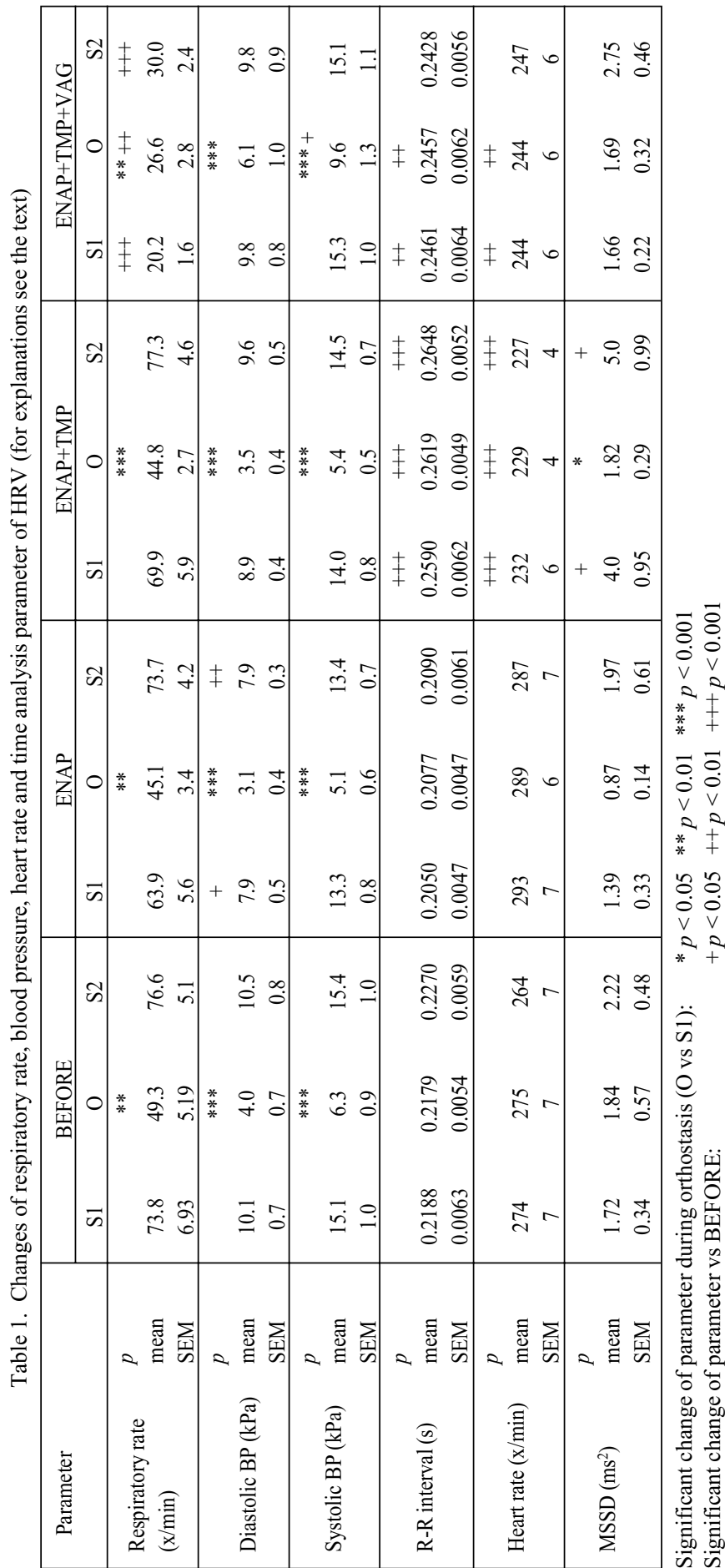

The R-R intervals (heart rate) were significantly changed during orthostasis neither BEFORE nor after interventions. The administration of TMP significantly increased the R-R intervals and after VAG these intervals decreased, but the values were still higher compared to BEFORE (Table 1, Fig. 3).

The MSSD values significantly increased in $\mathrm{S} 1$ and $\mathrm{S} 2$ positions after the administration of TMP. There was no significant change of MSSD during orthostasis BEFORE the interventions (Table 1).

The parameters of HRV evaluated by frequency analysis changed characteristically during orthostasis; the significant increase in TP was observed BEFORE, after ENAP as well as after TMP. However, after vagotomy there was significantly decreased TP in S1, O and S2 positions, with the moderate increase of TP during orthostasis (Table 2, Fig. 4).

The ENAP administration increased the relative power HF and LF in S1; on the contrary, relative power VLF decreased. During orthostasis, relative power LF and HF decreased, and relative power of VLF band increased. The lowest decrease and increase was observed only after vagotomy (Table 2).

In supine positions (S1, 


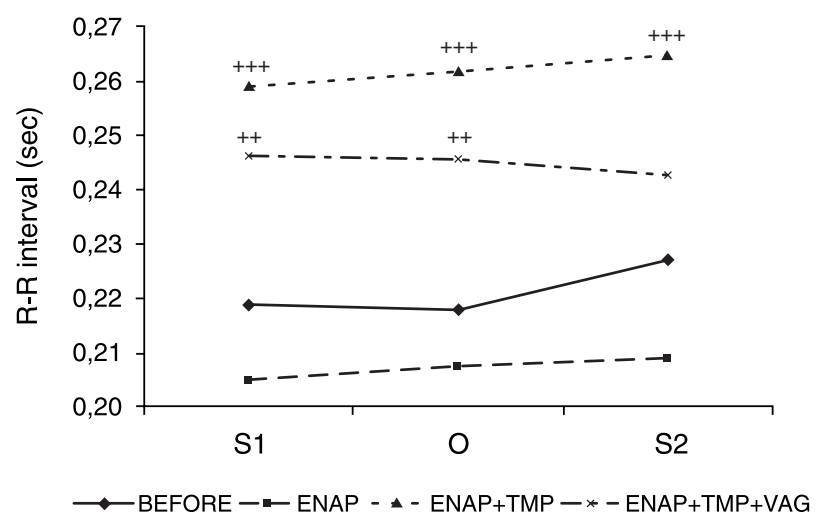

Fig. 3. Changes of R-R interval (for explanations see the text, for SEM see Table 1). Significant change of parameter vs BEFORE: $+p<0.05,++p<0.01,+++p<0.001$.

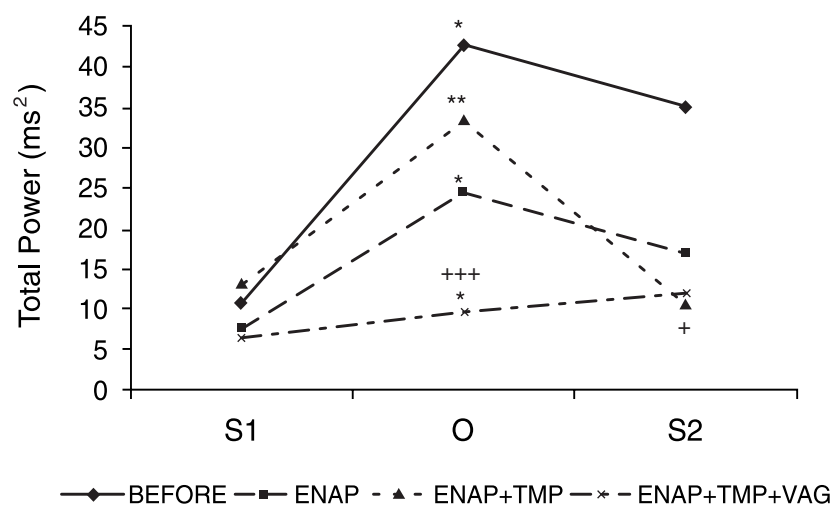

Fig. 4. Changes of Total Power (for explanations see the text, for SEM see Table 2).

Significant change of parameter during orthostasis (O vs S1): * $p<0.05, * * p<0.01, * * * p<0.001$. Significant change of parameter vs BEFORE: $+p<0.05,++p<0.01,+++p<0.001$.

$\mathrm{S} 2$ ), the ratio LF/HF was significantly changed only after TMP administration. The vagotomy did not increase this ratio, but led to decrease during orthostasis, which was significantly lower comparing to BEFORE, ENAP as well as TMP. The increase in ratio VLF/HF and VLF/LF evoked by orthostasis was blocked only after vagotomy (Table 2).

\section{Discussion}

During orthosthasis, almost all the indicators characterizing the essential life functions are changed. Contrary to humans, rabbits spend most of their life standing on four paws. Standing on two back paws they remain only for a short time, especially during seeking the food, however, the active muscle pump supporting the blood return from extremities to the heart is involved during this period. In our experiments we evoked a passive orthostasis. This was accompanied by significant decrease of respiratory rate, which was influenced neither by administration of ENAP, nor by TMP. Only bilateral vagotomy led to significant decrease of respiratory rate in supine positions and paradoxically, the orthostasis was 


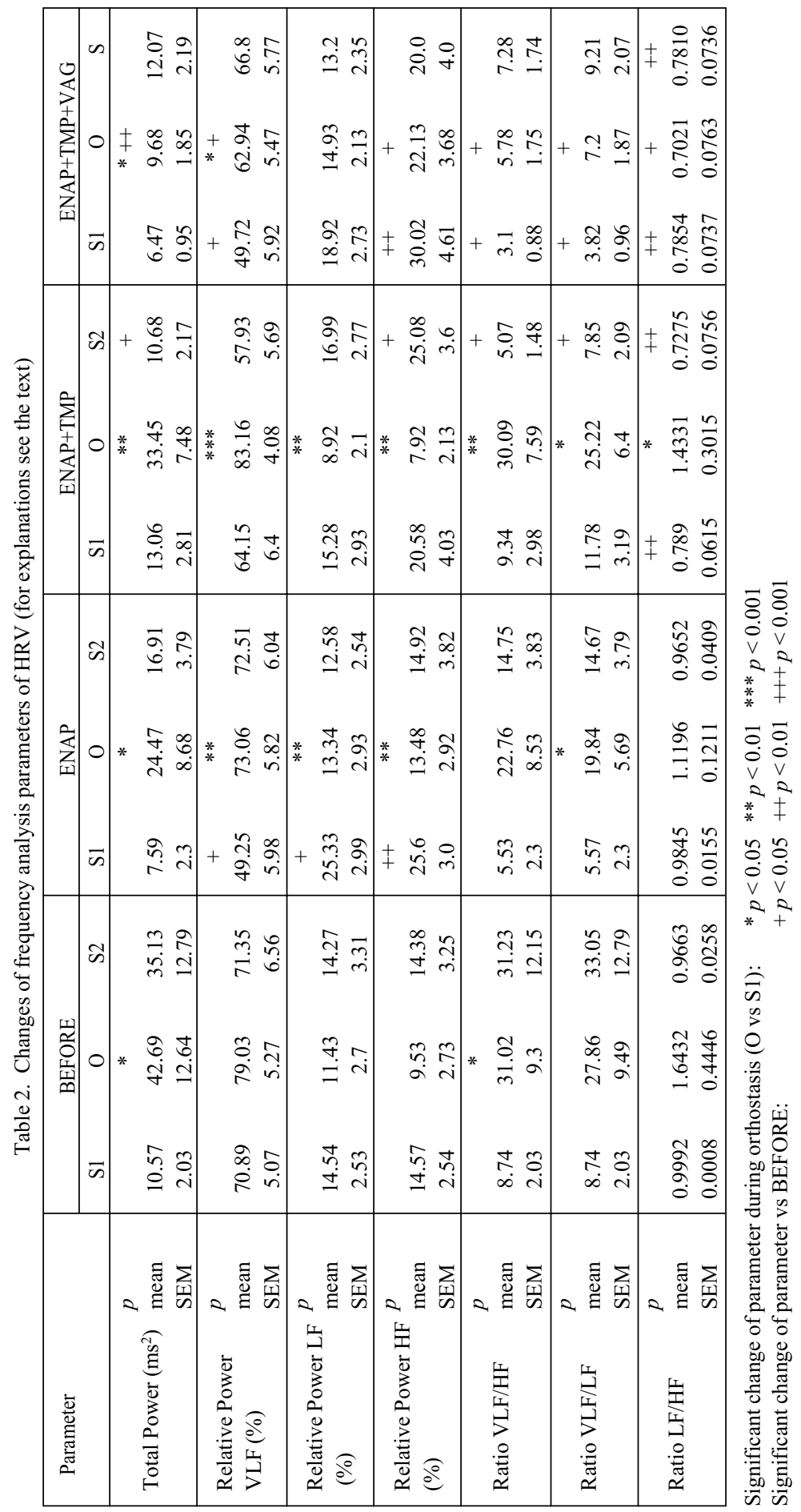


accompanied by increased respiratory rate. It suggests the participation of vagal receptors of airways and lungs, including slow-adapting pulmonary receptors - stretch receptors, as before vagotomy the orthostatic position caused decrease and after vagotomy increase of respiratory rate. The vagotomy interrupted the afferent innervations from pulmonary stretch receptors, leading to disinhibition of apneustic centre in medulla oblongata and to slowing and deepening the breath. These receptors are stimulated by e.g. traction of abdominal organs and by passive hyperinflation of lungs, not excluding also influence of lower perfusion of the brain. The latter possibility is supported by results of Gauer and Thron (1965), who found that in human during orthostasis there is blood flow in brain circulation lowered by $20 \%$ and more.

The orthostatic position led to higher accumulation of the blood in the parts of the body, which are below the heart level. In men it was quantified to $500-600 \mathrm{ml}$ in veins of lower extremities and 200-300 $\mathrm{ml}$ in pelvic and gluteal region (Buchanec and Javorka 1991). During prolonged orthostasis, a hypovolemia induced by filtration through the capillary wall due to increased filtration pressure can affiliate (S ander-Jen sen et al. 1986). As this and sitting position is physiological in humans (more than $2 / 3$ of day), there were developed several adapting mechanisms, including increase of heart rate during changing from horizontal (supine) to vertical (orthostatic) position. This reaction is conditioned firstly by lower parasympathetic tone and later by increased sympathetic activity (Ew ing et al. 1980). In rabbits, however, we did not observe any significant changes of heart rate during orthostasis. Furthermore, we observed a massive BP decrease during orthostasis. We suppose the decrease of BP was caused by lower venous return as well as by inability of the heart to adapt to this situation by increased heart rate. Both of these parameters indicate the missing compensatory mechanisms.

In humans, the blockade of RAA system by enalapril leads to lower BP by decreasing the peripheral vascular resistance without changing the heart rate (W a eber et al. 1995). In our study we confirmed the hypotensive effect of enalapril in rabbits. Furthermore, we observed a non-significant shortening the R-R interval (increased heart rate), probably as a result of the lower tonic activity of baroreceptors by decreased BP.

The decrease of heart rate in anaesthetized chinchilla rabbits after administration of TMP confirmed the regulatory influence of beta-sympathetic on the heart. Similar bradycardiac effect is observed also in humans. Metipranol, the non-selective beta-adrenergic blocker, does not possess the intrinsic sympathomimetic activity, which could keep an unchanged heart rate. Consecutive bilateral vagotomy led to increased heart rate, indicating some participation of parasympathetic nervous system in regulation of the heart rate in rabbits, too. However, after complete blockade of ANS influence on the heart function the heart rate was lower than before interventions. In humans, contrary, the complete denervation of the heart causes so called "intrinsic heart rate" (IHR) calculated by formula IHR $=118.1-(0.57$ $\times$ age), i.e. in 20 years old human it is $107 / \mathrm{min}$ (Jose and Collis on 1970). Summarizing this we can conclude that denervated heart in rabbits has lower heart rate than the heart with normal innervations, suggesting for predominance of sympathetic nervous system. This could reflect in decreased ability to activate the influence of sympathetic nervous system on the heart in rabbits during orthosthasis, i.e. to worsening the adaptation for this position.

We used the method of HRV analysis for the evaluation of the heart rate fluctuations. HRV is often used as a supplementary instrument to common investigation of cardiovascular system regulation in the clinical practice (Jav orka et al. 1999, T on haj zerová et al. 2000, Tonhajzerová 2005), as well as in experiments (Kawamoto et al. 1996; Iwao et al. 2000). The orthostatic reflex in humans is associated by shortening the R-R intervals (tachycardiac reaction) caused by increase of the activity of sympathetic nervous system and decrease of parasympathetic influence. This leads to decrease in the HRV, e.g. to lowering 
MSSD as the parameter of time analysis (Tonhajzerová 2000). Furthermore, also frequency analysis parameters (total power) are decreased especially due to decreased power of HF band. The ratio LF/HF is increased as a marker of compensatory mechanisms. On the contrary, in rabbits there were no significant changes of heart rate (R-R intervals) as well as of MSSD BEFORE as well as after complete blockade of ANS. The significant increase of MSSD after TMP in supine positions (S1 and S2) was caused by lower sympathetic influences on the heart. However, significant decrease of MSSD during orthostasis after TMP can reflect incomplete inhibition of sympathetic part of ANS.

While the parameters of time analysis decreased during orthostasis, the parameters of frequency analysis typical for activation of sympathetic nervous system (VLF and LF bands activities, ratios $\mathrm{LF} / \mathrm{HF}$ and $\mathrm{VLF} / \mathrm{HF}$ ) increased in rabbits. This confirms also the increase of TP. Generally in humans, the HF band is determined mainly by breathing and concomitant respiratory sinus arrhythmia mediated predominantly via activity of parasympathetic nervous system. The LF band reflects the baroreceptor activity and its changes are based on activity of both sympathetic and parasympathetic nervous system. The VLF band is predominantly influenced by activity of sympathetic nervous system, but certain role play parasympathetic nervous system and RAA system (Javorka et al. 1997) as well as thermoregulation and cyclic fluctuations in peripheral vascular tone (Kawamoto et al. 1996; Tonhajzerová and Javorka 2000; Tonhajzerová et al. 2000).

In our experiments, the significant increase of relative power HF in supine position after vagotomy could be based on higher tidal volume. This is in concordance with results of Iwao et al. (2000), who demonstrated the association of HF component of HRV with magnitude of fluctuations of vagal input associated with respiratory modulation. In supine position, the parasympathetic activity is predominant, while in orthostasis prevails the sympathetic activity, which can be significantly inhibited by administration of beta-blocker (Pagani et al. 1986). In all evaluated bands, contrary to humans the power increased during orthostasis. This increase was significantly blocked only after complete blockade of ANS, i.e. after TMP administration followed by vagotomy.

Regarding our results, we can confirm the fact that RAA system influences the HRV predominantly in VLF band; the administration of ENAP led to decreased relative power VLF.

However, in orthostasis the relative power VLF increased. We suppose that this effect would be expressed more after prolonged orthostasis, as the humoral RAA system activates only later by hypoperfusion of kidneys due to blood stagnation in lower extremities. Horký et al. (1974) showed that RAA system activates in humans during 5-15 minutes of orthostasis. On the contrary, relative power LF and HF decreased during orthostasis, indicating on attempt to release the sympathetic activation. This is confirmed also by significant increase of ratios $\mathrm{VLF} / \mathrm{HF}$ and $\mathrm{LF} / \mathrm{HF}$.

Significant decrease of ratio $\mathrm{LF} / \mathrm{HF}$ after administration of TMP gives evidence of determination the LF band by sympathetic nervous system as well as lower stimulation of high-pressure baroreceptors by decreased BP in rabbits. Paradoxically, vagotomy did not reverse this situation and there was not observed any increase of this ratio. We suppose that especially deepening of breath can participate in increase of POWER HF.

Furthermore, the inhibition of increase in ratio VLF/HF and VLF/LF during orthostasis only after bilateral vagotomy (and not after administration of TMP) points out on complexity of influences of sympathetic and parasympathetic nervous systems as well as RAA system in individual frequency bands in Chinchilla rabbits (Nadareishvili et al. 2002).

We conclude that the orthostasis in anaesthetized rabbits is accompanied by depression of respiratory rate reversed only by vagotomy. Furthermore, decrease of systemic blood pressure, unchanged heart rate and increased characteristics of heart rate variability were 
found, with predominant increase of spectral power in LF and VLF bands. This elevation can be eliminated only by complete blockade of ANS. Although the participation of sympathetic and parasympathetic nervous systems or RAA system in modification of individual HRV frequency bands is not as specific as in humans, we confirmed the participation of RAA system in determination of the VLF band.

\section{Zmeny frekvencie dýchania, krvného tlaku a variability frekvencie srdca u králikov počas ortostázy}

Cielom štúdie bolo hodnotenie zmien frekvencie dýchania, systémového tlaku krvi a parametrov variability frekvencie srdca (VFS) počas ortostázy u anestézovaných králikov. Okrem toho sme sledovali tieto zmeny po ovplyvnení systému renín-angiotenzín-aldosterón (RAA) a vegetatívneho nervového systému (VNS), čo umožnilo štúdium mechanizmov podielajúcich sa na aktivite jednotlivých frekvenčných pasiem VFS u králikov.

10 dospelých králikov (činčila) sme uspali pomocou ketamínu a flunitrazepamu. Počas pokusu sme zaznamenávali hodnoty systémového tlaku krvi, dychového objemu a frekvencie dýchania. VFS sme hodnotili pomocou mikropočítačového systému VariaPulse TF3E. R$\mathrm{R}$ intervaly boli odvodené z elektrokardiografického signálu získaného pomocou podkožných ihlových elektród. VFS sme hodnotili vo velmi nízko-(VLF; 0,01-0,05 Hz), nízko- (LF; $0,05-0,15 \mathrm{~Hz})$ a vysoko-frekvenčnom pásme (HF; $0,15-2,0 \mathrm{~Hz})$ a vypočítali sme parametre frekvenčnej a časovej analýzy. Merania prebiehali v horizontálnej (supinačnej) polohe, v ortostáze (uhol $60^{\circ}$ ) a v opätovnej supinačnej polohe pred a po podaní enalaprilu $(0,5 \mathrm{mg} / \mathrm{kg}$ ž.h.), metipranololu (0,2 $\mathrm{mg} / \mathrm{kg}$ ž.h.) ako aj po následnej obojstrannej cervikálnej vagotómii.

Ortostáza bola u anestézovaných králikov sprevádzaná poklesom frekvencie dýchania, ktorý vymizol až po vagotómii. Okrem toho došlo k poklesu systémového tlaku krvi pri nezmenenej frekvencii srdca. Tieto zmeny boli sprevádzané zvýšenými hodnotami VFS, a to najmä zvýšením spektrálneho výkonu v LF a VLF pásme, ktorý bol eliminovaný až úplnou blokádou VNS.

Napriek tomu, že na zmenách jednotlivých frekvenčných pásiem VFS sa VNS a RAA systém nepodielajú tak špecificky ako u ludí, potvrdili sme účast RAA systému v podmieňovaní aktivity VLF pásma.

\section{Acknowledgements}

The authors thank S. Svorková, D. Kulišková, M. Barčíková, M. Petrášková, and I. Štritz for technical assistance. The experiments were carried out with consent of the Ethical Committee, Faculty of Medicine, Jessenius University, Martin, Slovakia.

\section{References}

BUCHANEC J, JAVORKA K 1991: The effect of orthostasis on some parameters of circulation in selected so called psychosomatic diseases in children. Folia Med Martinensis 18: 175-183

EWING DJ, CAMPBELL TW, CLARKE BV 1980: Assessment of cardiovascular effects in diabetic autonomic neuropathy and prognostic implications. Ann Intern Med 92: 308-311

GAUER OH, THRON HL 1965: Postural changes in circulation. In: Hamilton, WF (Ed.): Handbook of Physiology, Section 2, Vol 3. Amer Physiol Soc, Washington D.C., pp. 2409-2439

HORKÝ K 1974: System rennin-angiotensin and its importance for clinical practice (in Czech). Avicenum, Praha, $194 \mathrm{p}$.

IWAO T, YONEMOCHI H, NAKAGAWA M, TAKAHASHI N, SAIKAWA T, ITO M 2000: Effect of constant and intermittent vagal stimulation on the heart rate and heart rate variability in rabbits. Jpn J Physiol 50: 33-39

JAVORKA K 1992: Postural changes of respiration and blood pressure in premature neonates (in Slovak). Bratisl Lek Listy 93: 346-351

JAVORKA K 1996: Methods and benefits of examining the heart rate regulation in children (in Slovak). Ces Pediat 51: $462-468$ 
JAVORKA K, JAVORKOVÁ J, PETRÁŠKOVÁ M, PARÍŽEKOVÁ I, BUCHANEC J, CHROMÁ O 1997: Heart rate variability in young patients with diabetes mellitus type I (in Slovak). Ces Pediat 52: 17-22

JAVORKA K, JAVORKOVÁ J, PETRÁŠKOVÁ M, TONHAJZEROVÁ I, BUCHANEC J, CHROMÁ O 1999: Heart rate variability and cardiovascular tests in young patients with diabetes mellitus type 1. J Pediat Endocrin Metab 12: 423-431

JOSE AD, COLLISON D 1970: The normal range and determinants of the intrinsic heart rate in man. Cardiovasc Res 4: $160-167$

KAWAMOTO M, KANEKO K, HARDIAN, YUGE O 1996: Heart rate variability during artificial ventilation and apnea in brain-damaged rabbits. Am J Physiol 271: H410-H416

KLEIGER RE, STEIN PK, BOSNER MS, ROTTMAN JN 1992: The domain measurements of heart rate variability. Cardiol Clin 10: 487-498.

NADAREISHVILI KSH, MESKHISHVILI II, KAKHIANI DD, ORMOTSADZE GL, NAZARISHVILI GT, GVASALIA MG, KHVEDELIDZE MT, SANDODZE VY 2002: Heart rate variability in Chinchilla Rabbits. Bull Exp Biol Med 134: 568-570

PAGANI M, LOMBARDI F, GAZZETTI Z 1986: PSA of heart rate and arterial pressure variability. SE marker of sympatho-vagal interaction in man and conscious dog. Circ Res 59: 178-193

SALINGER J, OPAVSKÝ J, BÚLA J, VYCHODIL R, NOVOTNÝ J, VAVERKA F 1994: Software equipment of measure instrument TF-2 for spectral analysis of variation of R-R interval in cardiology (in Czech). Lékař a technika 25: 58-62

SALINGER J, OPAVSKÝ J, NOVOTNÝ J, VYCHODIL R, VAVERKA F, HUDCOVÁ Z 1993: Software equipment of measure instrument TF-2 for diagnostics of autonomous neuropathy (in Czech). Lékař a technika 24: $133-138$

SANDER-JENSEN K, SECHER NH, ASTRUP A, CHRISTENSEN NJ, GIESE J, SCHWARTZ TW, WARBERG J, BIE P 1986: Hypotension induced by passive head-up tilt: endocrine and circulatory mechanisms. Am J Physiol Regul Integr Comp Physiol 251: R 742-R748

TONHAJZEROVÁ I 2000: Heart rate variability and the benefit of its evaluation in physiological research (in Slovak). $\mathrm{PhD}$ thesis. Comenius University, Bratislava, $133 \mathrm{p}$.

TONHAJZEROVÁ I 2005: Autonomic nervous system (ANS) and the possibilities of ANS activity assessment in obesity (in Slovak). Ces Pediat 60: 228-234

TONHAJZEROVÁ I, JAVORKA K 2000: Evaluation of heart rate variability and its benefit (in Slovak). Ces Fysiol 49: 51-60

TONHAJZEROVÁ I, JAVORKA K, PETRÁŠKOVÁ M 2000: Changes of heart rate variability in mental stress (in Slovak). Ces Pediat 55: 562-567

WAEBER B, NUSBERGER J, BRUNNER HR 1995: Angiotensin-converting enzyme inhibitors in hypertension. In: Laragh JH, Brunner BM: Hypertension: Pathophysiology, diagnosis and management. 2nd Edition. Raven Press, New York, pp. 2861-2875 